Arab World English Journal (AWEJ) $2^{\text {nd }}$ Special Issue on Covid 19 Challenges January 2022 DOI: https://dx.doi.org/10.24093/awej/covid2.1

\title{
Exploring Online Writing Assessment Amid Covid-19: Challenges and Opportunities from Teachers' Perspectives
}

\author{
Abdullah Al-Bargi \\ English Language Institute \\ King Abdulaziz University, Jeddah, Saudi Arabia \\ Email: aalbargi@kau.edu.sa
}

Received:11/8/2021

Accepted: 12/17/2021

Published: $1 / 24 / 2022$

\begin{abstract}
Remote online second language (L2) writing instruction, in general, and remote online L2 writing assessment, in particular, require a holistic structural approach that results in improving students' L2 writing, as well as offering an authentic and fair assessment of students' L2 writing performance. The study described in this paper employed a convergent parallel mixed methods approach where the Covid-19 pandemic, as well as the purpose of the research, necessitated the adoption of this research design since it can provide the basis for answering the question: What impact did full mode online teaching have on L2 education. In the survey part of the research, 241 English as a Foreign Language (EFL) teachers working in Saudi Arabia participated in a custom-designed 30-item questionnaire utilizing a five-point Likert scale. In the qualitative part of the study, nine EFL teachers (four males and five females) participated in a semi-structured interview which lasted from thirty-five to fifty minutes. A detailed analysis of both the quantitative and qualitative primary data indicated that EFL teachers are aware of the importance of rubrics and standardized assessment procedures in awarding fair grades to students. Teachers also highlighted several important advantages of teaching online L2 writing remotely. However, the vast majority of teachers questioned the accuracy of online writing assessment, indicating the need for a more developed model for the post Covid-19 era. Recommendations included the adoption of unanimously suggested practices (by participating teachers) in teaching remote online L2 writing as well as mandating the presence of the students onsite during the sitting of the writing exams, thus providing the assurance of authenticity of students' performance in the writing exams as well as the possibility to monitor all the students while they sit the exams.
\end{abstract}

Keywords: Academic integrity, Covid-19, English language teaching, English as a foreign language, online writing assessment, Saudi EFL teachers

Cite as: Al-Bargi, A. (2022). Exploring Online Writing Assessment Amid Covid-19: Challenges and Opportunities from Teachers' Perspectives. Arab World English Journal (AWEJ) $2^{\text {nd }}$ Special Issue on Covid 19 Challenges (2) 3-21.

DOI: https://dx.doi.org/10.24093/awej/covid2.1 
Arab World English Journal (AWEJ) 2nd Special Issue on Covid 19 Challenges January 2022

\section{Introduction}

\section{Reason for the Study}

The entire global education process was upended by the Covid-19 pandemic. The implementation of full to partial lockdown in the majority of countries around the world had a powerful impact on onsite educational programs, resulting in a 180-degree shift to mandatory full-time online teaching and learning (Mondol \& Mohiuddin, 2020). With such a sudden disruption of the onsite status quo in nearly every country around the world, new challenges surfaced in English Language Teaching (ELT) (Jiang et al., 2021; Subekti, 2021; Yi \& Jang, 2020).

Among these challenges are the various online ELT assessment practices that are required to be both effective and fair to the students. These challenges did not surface only during the Covid-19 pandemic with its mandatory lockdowns and full online teaching and learning protocols, but rather, were noted even before the pandemic. There have been various research studies on online formative and summative assessment best practices as well as on the academic integrity of students' work (e.g., writing skills) where the focus was on strategies to eliminate plagiarism and cheating (Alghamdi et al., 2016; Olt, 2002; Sileo \& Sileo, 2008).

However, the scale and impact of the sudden shift towards full online learning raised concerns within the ELT field as most teachers had not been prepared professionally for full-time online teaching. This also meant that it was imperative to develop an effective model for online assessment. Notwithstanding the aforementioned criticality of remote online L2 teaching in general and remote online L2 writing in particular, it is also imperative to consider the broader aspect of remote teaching which also offers several positive characteristics and potentiality for pedagogical approaches for L2 teachers. It is now appropriate to conduct a detailed and thorough study not merely to address the downsides and elements of concern related to online L2 assessment, but also to chart a path forward for realizing better online writing assessment, addressing both the pros and cons of full online assessment as perceived by the L2 teachers. Such research studies are indispensable since the migration to full online learning is indicative of the need to mitigate online assessment challenges as well as provide teachers with support and opportunities to conduct a thorough as well as fair assessment. Furthermore, an exploration of the best practices in various online L2 assessment components can certainly provide L2 teachers with the necessary tools to fulfil the curriculum aims and objectives. Once we view the pros and cons of L2 online writing assessment, we can, eventually, formulate a pedagogical model for EFL teachers to follow in order to promote best ELT practices as well as second language acquisition (SLA).

\section{Significance of the Study}

This research offers an authentic reflection from within the ELT profession by EFL

teachers who have had first-hand experience with the migration from onsite to online learning due to the Covid-19 pandemic outbreak. It is unique in that it explores an educational phenomenon within the relevant time frame. Furthermore, the study aims to consolidate previous research regarding challenges of and opportunities for online learning, especially on the fullmode online platforms, in general, with a focus on remote writing assessment which can involve issues of academic integrity as well as mark inflation of students' online submitted written work (Austin et al., 2021; Penrod, 2005). 
Arab World English Journal (AWEJ) 2nd Special Issue on Covid 19 Challenges January 2022

\section{Research Questions}

The study was guided by the following three research questions:

1. What impact has the migration from onsite to online writing assessment had on the assessment of writing as perceived by EFL teachers?

2. What are the challenges that EFL teachers have experienced regarding writing assessment within the fully online teaching and learning environment?

3. What are the advantages and positive outcomes that EFL teachers have experienced during the fully online L2 writing teaching and assessment that resulted from the Covid19 lockdown?

\section{Research Objectives}

This research aims to explore the challenges that EFL teachers in the Saudi context have experienced with regards to remote L2 writing assessment during the migration from onsite to online learning due to the Covid-19 pandemic outbreak. Additionally, the study aims to explore the advantages and benefits of the full online L2 writing teaching and learning environment in general, as well as the L2 writing assessment, in particular, as perceived by the EFL teachers surveyed.

\section{Literature Review}

Prior to March 2020, (nearly 18 months ago at the time of writing), education shifted from fully onsite teaching at schools, colleges and universities to fully remote online teaching and learning (König et al., 2020). Since then, several onsite pedagogical parameters have been abandoned and replaced by new approaches befitting pedagogical strategies as per the demands of the new, fully online teaching and learning environment (Kidd \& Murray, 2020). Yang and Huang (2021) indicate that: "The outbreak of COVID-19 has triggered a worldwide upsurge in online education...Despite being expedient, such a large-scale migration of higher education from on-site to online has produced valuable educational experience and implications, that deserve to be preserved and leveraged in the future" (p. 121).

With such a monumental shift in the learning environment, it is crucial that the integrity of the educational process be upheld since the essential outcome aims in an online environment are the same as those in an onsite environment. Md Yunus et al. (2021) state that:

Online learning has become essential to education as the Covid-19 pandemic has brought significant changes to the field. However, education should remain welcoming and supportive to all the learners as it is important to keep the students' behavioural intention in any form of learning environment (p. 1).

Language Assessment can take several forms depending on the purpose for the assessment. Mihai (2010) organizes the types of assessment into five categories: mode (oral or written), intention (informal and formal), purpose (formative and summative), interpretation (normreferenced and criterion-referenced) and administration (classroom-based and large scale). As far back as the 1980s, the teaching, assessment and corrective feedback (in response to the students' submitted written work) relating to writing skills in an L2 has been heavily debated among linguists and specialists in the field (Bitchener, 2008; Brown, 2012). This debate has also been a recurring topic in EFL teaching and learning circles in Saudi Arabia (Grami, 2010; Obeid, 2017; Rajab, 2018). Such research studies predated the Covid-19 outbreak and the 
Arab World English Journal (AWEJ) 2nd Special Issue on Covid 19 Challenges January 2022

migration to fully online learning. Notwithstanding, various learning management systems designated as virtual education platforms have numerous features enabling e-assessment to be conducted and students' performances evaluated (Sahidu et al., 2019).

However, new parameters and challenges emerged as mandatory lockdowns were implemented, and fully online teaching and learning were imminent. Several ELT researchers have explored the various tenets of teaching L2 writing both online and onsite (Jianling, 2018; Waer, 2020; Zyad, 2016). Prior to the Covid-19 outbreak, the writing assessment process: "was mainly academically oriented and highly dependent on memory. There has been a huge emphasis in examinations on only the productivity" Althaqafi (2018, p. 219). Althaqafi further asserts that in recent years, assessment, which has been utilized for purposes of testing and not much more, has evolved into a multi-purpose component that has been integrated into the EFL curriculum.

As education shifted towards the integration of technology and collaborative platforms for learning, emergent challenges surfaced. Numerous researchers confronted such challenges and explored ways to ameliorate them. Issues relating to academic dishonesty (cheating) and plagiarism were prominent issues in online assessment. Indeed, online assessment comes with various issues that make it a highly debatable issue among L2 and EFL teachers (Alghamdi et al., 2016). As fully online learning became the norm internationally during the peak of the Covid-19 pandemic, the new face of education paved the way for teachers in many disciplines and in EFL in particular, to have an opportunity to reflect on challenges as well as new opportunities in implementing best practices in ELT (Atmojo \& Nugroho, 2020). Elements relating to teachers' as well as students' engagement, learners' autonomy, motivation of both teachers and students, fulfilment of curriculum aims and objectives, and the newly gained experiences of fully online teaching and learning, are all just a part of the holistic encapsulation of online learning.

It is important, however, to envisage the L2 online writing assessment as a process that is preceded by all the variables of L2 pedagogies relating to writing skills and also, as a process leading to testing (Guo \& $\mathrm{Xu}, 2021$ ). A holistic research approach with a comprehensive exploration of the online writing assessment process is indispensable to the field of ELT. It is imperative to allow the EFL teachers to express their views unreservedly. Such an approach is necessary to view the process from all perspectives and take into consideration the pros and cons.

Within EFL contexts, in general, and the Saudi EFL context, in particular, a few studies managed to explore one or two aspects of writing assessment. A study by Zou et al. (2021) explored the engagement of just three teachers with formative assessment during the Covid-19 pandemic in the Chinese EFL context. They also explored the factors that influenced those three EFL writing teachers' engagement with the online formative assessment. The researchers identified three types of teacher engagement -- disturbing, auxiliary and integral -- which are influenced by the EFL teachers' own beliefs, digital literacies and ELT experiences. AlTameemy et al. (2020) explored the perception of 660 university students in Saudi Arabia regarding eassessment on a learning management system platform (BlackBoard $®$ ) in which they reported that the majority of the students expressed a positive attitude towards e-assessment. Another study by Alghamdi et al. (2016) surveyed the opinion of Saudi university students regarding their perception of collaboration on a given written assignment. The researchers concluded that the majority of those surveyed did not consider communication with each other as a form of 
academic dishonesty or plagiarism since those students were not aware that the regulations regarding online writing assessment were in parallel with an onsite learning environment. This suggests that a transition to online learning must be accompanied by an explanation of what is expected of students and why, despite the change in learning environment, the rules surrounding expectations and student conduct remain the same.

A more focused research study in the Saudi EFL context was conducted by Almossa (2021) who explored the students' perceptions of their online learning e during the Covid-19 pandemic outbreak. She concluded that students' engagement with learning and assessment was greatly affected by the sudden change from onsite to online where they faced several challenges: coping with the online platform, heavy demand of assignments, and family issues due to the Covid-19 pandemic. She further asserted that: "Open communication between students and faculty are essential for ensuring shared understanding and acceptance. Additionally, departmental support and mediation between students and faculty members is necessary and should be a priority in cases where communication is lacking." (p. 1).

Equally important are the newly learned components and perceived advantages that are apparent with fully online teaching and learning. Positive elements can be an extension of research studies conducted before the pandemic which advocated the benefits of L2 remote online writing (Godwin-Jones, 2018; Griffith, 2014; Han \& Shin, 2017) or they can be the result of studies conducted post Covid-19 where new parameters of benefits may have been manifested and experienced by L2 teachers as a result of online teaching and assessment during the pandemic (Balouchi \& Samad, 2021). Shin et al. (2021) affirm that L2 students find it more convenient to use various language-support resources available online. They found that students who had access to online writing resources outperformed those students who were not given access to such resources.

However, there have been very few research studies that have explored the parameters of L2 full-mode online learning with regards to challenges and opportunities in general and to online writing assessment following the Covid-19 pandemic outbreak in the Saudi context. As such, the current research study will address both the concerns that EFL teachers have regarding the shift in writing assessment from onsite to online teaching platforms, as well as the positive outcomes which have occurred as a result of the first-hand experience of teachers with online educational environments.

\section{Methodology}

This research is intended to delve into the subject of online writing assessment during the Covid-19 lockdown and teachers' observations of the pros and cons of migration from onsite to fully online learning. As such, the best approach to answering the three research questions is to adopt a convergent parallel mixed methods research design. Creswell (2014) states that:

The intent of a convergent design is to merge the results of the quantitative and qualitative data analyses. This merging then provides both a quantitative and a qualitative picture of the problem, and because both forms of data provide different insight, their combination contributes to seeing the problem from multiple angles and multiple perspectives. (p. 35). 
Arab World English Journal (AWEJ) 2nd Special Issue on Covid 19 Challenges January 2022

\section{Participants and Procedures \\ Sampling}

In order to screen any bias on the part of individual EFL teacher participants, simple random, probability sampling was chosen for this study. EFL teachers, regardless of their age, gender, nationality and years of experience, were given an equal opportunity to participate. In total, EFL teachers from 15 universities were contacted, and the survey link was made available for any EFL teacher wishing to participate. A total of 241 English as a Foreign Language (EFL) teachers, both male and female, participated in a custom-designed survey. In addition, nine EFL teachers (four male and five female) took part in semi-structured interviews. See more information about the participants in Tables 3, 4, 5, and 6 in the Appendices.

\section{Data Collection Tools}

The primary data collection tools consisted of two instruments. The first instrument was a 30-item questionnaire on a 5-point Likert scale, and the second instrument was a 40-minute semi-structured interview.

\section{Data Collection Procedure}

The primary data collection procedure from both tools, the survey and the semistructured interviews tool, were conducted online via a survey host website as well as the Zoom ${ }^{\circledR}$ meeting collaborative platform. The link to the survey was sent electronically via email. Also, those who expressed interest in participating in the interviews were given the opportunity to provide their details at the end of the survey. Those who did not wish to participate did not have to give any details. In order to maximise the opportunities for as many EFL teachers as possible to participate, the survey link was made available for six months, which allowed ample time for EFL teachers to participate while providing the opportunity to fully and carefully consider responses to each item in the survey.

\section{Validity}

The validity, as a measurement of the accuracy of the questionnaire as a data collection tool (Nardi, 2018), was evaluated before the finalized draft questionnaire was sent to the participants. Face validity was evaluated by two experts in the ELT field (two assistant professors) who endorsed the questionnaire and approved its layout. The content validity was then evaluated via the piloting of the questionnaire with 10 EFL teachers who completed the survey without any concerns or difficulties. The gathered data from the pilot stage was discarded and the participants who took part in the pilot stage did not participate in the main data collection stage.

On the other hand, the validity of the qualitative data was achieved by ensuring the "trustworthiness" of the qualitative data in terms of credibility, transferability, dependability and confirmability (Klenke et al., 2016). The researcher revisited some of the data and re-confirmed the interpretation with four of the participants. Furthermore, the researcher compared several elements of the gathered qualitative data and the analyses that followed, with other relevant studies. The data of this research was found to be comparable and was corroborated by other studies in the field. Thus, confirmability was achieved via comparability and corroboration of this research with other parallel research studies. 


\section{Reliability}

The reliability of the primary data gathered from the responses to the questionnaire items was measured via the calculation of the Cronbach's alpha as a measurement of the internal consistency of the ordinal data (responses) to the Likert items of the questionnaire (Items 9 to 30, barring Item 14). The formula used to calculate the Cronbach's alpha was as follows:

$$
\alpha=\frac{K}{K-1}\left(1-\frac{\sum S 2 y}{S 2 \mathrm{x}}\right) \text { (Yudkowsky et al., 2019). }
$$

Where $\alpha$ is the Cronbach's alpha value, $k$ is the number of items, $\sum S 2 y$ is the sum of item variance and $S^{2} x$ is the variance of total score. The resultant generated value was .830 which is considered a good (internal consistency indicator) value for the Likert items data (Tavakol \& Dennick, 2011). Table 1 shows the Cronbach's alpha formula calculation.

Table 1. Cronbach's alpha calculation.

\begin{tabular}{|c|c|c|}
\hline Variables & Description & Values \\
\hline$K$ & \# of items & 21 \\
\hline$\sum S^{2} y$ & sum of the item variance & 13.44 \\
\hline$S^{2} X$ & variance of total score & 64.06 \\
\hline$\alpha$ & Cronbach's alpha & 0.830 \\
\hline
\end{tabular}

With such a good internal consistency value, the researcher proceeded with normality tests to determine whether the data is normally distributed and to thus use parametric statistical analysis methods or, not normally distributed and in that case to use non-parametric statistical analysis methods. Descriptive statistical tests of normality (Kolmogorov-Smirnov ${ }^{\text {a }}$ for a data set that is larger than 100) revealed that the data is not normally distributed where the calculated values of significance indicated that they are less than 0.05 and thus, are significantly different statistically.

Table 2. Tests of Normality of the responses to the Likert-type items of the questionnaire.

\begin{tabular}{|l|r|r|r|r|r|r|}
\hline \multicolumn{10}{|c|}{ Tests of Normality } \\
\hline & \multicolumn{2}{|c|}{ Kolmogorov-Smirnov ${ }^{\text {a }}$} & \multicolumn{3}{c|}{ Shapiro-Wilk } \\
\cline { 2 - 7 } & Statistic & \multicolumn{1}{c|}{ df } & \multicolumn{1}{c|}{ Sig. } & Statistic & \multicolumn{1}{c|}{ df } & \multicolumn{1}{c|}{ Sig. } \\
\hline Online & .118 & 241 & .000 & .943 & 241 & .000 \\
\hline Cheating & .168 & 241 & .000 & .935 & 241 & .000 \\
\hline Online Assess & .125 & 241 & .000 & .953 & 241 & .000 \\
\hline
\end{tabular}

As a result, the researcher conducted non-parametric statistical analysis methods for the primary data gathered from the questionnaire.

\section{Data Analysis}

The process of concurrently analysing the gathered primary data was completed utilising the IBM SPSS Statistics $27 \AA$ and MS Excel ${ }^{\circledR}$ for the quantitative data, while the qualitative data which was transcribed verbatim from the audio recordings of the semi-structured interview, was manually coded and then, thematically analysed for emergent themes (Saldana, 2021). 


\section{Part I: Demographics}

The questionnaire contained seven questions about demographics. These questions showed that nearly one third of the participants were male EFL teachers $(32 \%)$ and two thirds were female $(68 \%)$. They also showed that the majority of the participants $(58 \%)$ were from the Western region, followed by the Central region (14\%), then the Southern and Eastern regions (12\% each) and finally, the Northern region (4\%) (see Table 3 - Appendix). 58\% of the respondents had a master's degree and $25 \%$ had a doctorate, as further detailed in Table 4 (Appendix). The majority of participants (around 51\%) had between 11 and 20 years of experience, while those with 0-10 years of experience accounted for about one-third (see Table 5 - Appendix - for full details). However, as Table 6 (Appendix) shows, the vast majority of teachers $(84 \%)$ had less than three years of experience teaching online. As far as institutional context, just over half of the participants taught in 15-week full semesters (56\%) while $44 \%$ taught in a modular, 7-week system. In addition, the majority of institutions where the teachers worked offer a mixture of courses (at 50\%) and not general English only or PYP English only (see Table 7 - Appendix - for full details).

\section{Part II: Perception of Remote Unproctored Online Writing Assessment (issues of concern)}

Following the demographic questions, the next question asked respondents whether the remote online writing assessments they graded were proctored or unproctored. Almost 50\% of the exams were unproctored with an additional 11\% "sometimes unproctored". See Table 8 (Appendix) for additional details.

In Part II (and Part III), the Likert items responses were designated a numerical value for descriptive statistics purposes. These values are: Strongly Agree $=1$, Agree $=2$, Neutral $=3$, Disagree $=4$, Strongly Disagree $=5$. The higher the mean values (e.g. $>3$ ), the stronger the indication that the opinions are geared towards strong disagreement. The lower the mean values are (i.e. $<3$ ), the stronger the indication that the opinions are geared towards stronger agreement.

Given that a large percentage of online writing exams were unproctored, Questions 9-13 in the questionnaire were designed to elicit teachers' perceptions of the validity of remote online writing exams both in situations where they are proctored and in situations where they are not proctored. Question 9 asked respondents about whether rubrics were provided for online writing assessment, Questions 10 and 13 asked whether the teachers thought the written work submitted was authentic and reflected students' actual language proficiency and Questions 11 and 12 asked about the authenticity of unproctored and proctored writing exams respectively.

As can be seen in Table 9 below, the descriptive statistics indicated that the majority of the teachers agreed that their institutes provide full rubrics for online writing (Item 9). As for whether the exams reflected students' true proficiency (Item 10), teachers were solidly in the middle, suggesting that they at best thought the written work submitted online "somewhat" reflected the students' true proficiency. In Item 13, teachers were even less confident that the submitted writing tasks were authentic, with most of them strongly agreeing that "It is difficult to verify the authenticity of writing assessment tasks if they are done remotely." This is further reflected in their answer to Question 11 where they strongly disagreed with the statement that remote unproctored online writing assessment can be as authentic as onsite assessment (Item 11). Interestingly, however, they were not quite as pessimistic about the statement, "Remote 
Arab World English Journal (AWEJ) 2nd Special Issue on Covid 19 Challenges January 2022

proctored online writing assessments can be as authentic as onsite assignments" (Item 12). Their response was solidly in the middle as was their response to whether the exams reflect students' true language proficiency (Item 10 already discussed above).

Table 9 Remote Online Assessment Teachers' Reflection (Items 9-13).

\begin{tabular}{|l|c|c|c|c|c|}
\hline & $\mathrm{N}$ & Minimum & Maximum & Mean & Std. Deviation \\
\hline $\begin{array}{l}\text { 9 Our institute provides full } \\
\text { rubrics for online writing } \\
\text { assessment. }\end{array}$ & 241 & 1.00 & 5.00 & 1.8340 & 1.22706 \\
\hline $\begin{array}{l}\text { 10 Students' written work } \\
\text { submitted in remote online writing } \\
\text { exams reflects their true language } \\
\text { proficiency. }\end{array}$ & 241 & 1.00 & 5.00 & 3.2407 & 1.33548 \\
\hline $\begin{array}{l}11 \text { Remote unproctored online } \\
\text { writing assessment can be as } \\
\text { authentic as onsite assessment. }\end{array}$ & 241 & 2.00 & 5.00 & 3.9793 & 1.13449 \\
\hline $\begin{array}{l}12 \text { Remote proctored online } \\
\text { writing assessments can be as } \\
\text { authentic as onsite assessment. }\end{array}$ & 241 & 1.00 & 5.00 & 3.2697 & 1.47686 \\
\hline $\begin{array}{l}\text { 13 It is difficult to verify the } \\
\text { authenticity of writing assessment } \\
\text { tasks if they are done online } \\
\text { remotely. }\end{array}$ & 241 & 1.00 & 5.00 & 2.1494 & \\
\hline Valid N (listwise) & 241 & & & & \\
\hline
\end{tabular}

Item 14 below relates to the perception of teachers regarding the number of students who received unauthorized help with their remote online assessment. As shown in Table 10 below, the majority of the teachers indicated that a large proportion of their students may have received unauthorized help with their online assessment.

Table 10. Percentage of Students Receiving Unauthorised Help. (Item 14).

\begin{tabular}{|l|c|c|c|c|c|}
\hline & $\mathrm{N}$ & Minimum & Maximum & Mean & Std. Deviation \\
\hline $\begin{array}{l}\text { 14 How many of your students do } \\
\text { you feel received unauthorized } \\
\text { help with their remote online } \\
\text { writing assessments? }\end{array}$ & 241 & 1.00 & 4.00 & 2.8133 & .81291 \\
\hline Valid N (listwise) & 241 & & & & \\
\hline
\end{tabular}

The above responses of the majority of the teachers have been echoed in the simultaneous, qualitative data analysis from the semi structured interviews. Participant B (female teacher), with over 12 years of experience in the ELT field, commented on what she experienced with full migration from onsite to online by saying: 
Arab World English Journal (AWEJ) 2nd Special Issue on Covid 19 Challenges January 2022

"I personally think that this transformation has made a very positive impact in alerting us to the actual paradigmatic shift from on site to online and necessitates the adaptation of suitable methods. However, I feel as if there are a few lessons to be learned and for issues to be addressed such as authenticity and whether the students are actually delivering the work themselves without receiving authorised or unauthorised help from anyone else".

Similarly, Participant G (male) expressed his perspective on the transformation from onsite to online due to the Covid-19 pandemic outbreak:

"The change has affected us immensely. The online writing assessment needed a lot of planning and preparation. I didn't know the students; I haven't seen them before and therefore it was literally impossible to verify who they were without the webcams or otherwise".

The next table focuses in detail on the questions asked teachers about online writing assessment. The majority of the teachers strongly disagreed with the statement that they can provide definitive evidence of cheating in an unproctored remote online writing assessment (Item 15). However, as noted in the answers to Item 13 previously, many teachers suspected cheating even though they did not have definitive evidence. The majority of the teachers strongly agreed that they preferred conducting all assessments in person (Item 16). The majority also strongly disagreed that the only skill they prefer to assess in person is the writing skill (Item 17). The majority of the teachers agreed that the two skills they would prefer to assess in person are writing and speaking (Item 18). This does not necessarily contradict Item 16 where teachers said they preferred conducting all assessments in person. They weren't asked specifically about listening and reading so we don't know what they would have said about those two skills. However, from Item 18 we can clearly see that at a minimum, teachers thought speaking and writing should be assessed in person.

Regarding Item 19, the majority of the teachers agreed that remote online writing assessment is more convenient to conduct than onsite assessment (Item 19). Similarly, the majority agreed that remote online writing assessment is less stressful for students than onsite assessment (Item 20). They also agreed that a blended style of online-onsite writing assessment is a good approach to measuring writing ability (Item 21). They also agreed with the statement that online writing assessment has increased students' digital literacy (Item 22). Table 11 illustrates these findings.

Table 11. Descriptive Statistics (Items 15 - 22).

\begin{tabular}{|l|c|c|c|c|c|}
\hline & $\mathrm{N}$ & Minimum & Maximum & Mean & Std. Deviation \\
\hline $\begin{array}{l}\text { 15 I can provide definitive evidence } \\
\text { of cheating in unproctored remote } \\
\text { online writing assessment. }\end{array}$ & 241 & 3.00 & 5.00 & 4.1120 & .71290 \\
\hline $\begin{array}{l}\text { 16 I prefer conducting all } \\
\text { assessments of English language } \\
\text { skills in person. }\end{array}$ & 241 & 1.00 & 4.00 & 1.6971 & .69788 \\
\hline $\begin{array}{l}\text { 17 The only English language skill } \\
\text { I'd prefer to assess in person is } \\
\text { writing. }\end{array}$ & 241 & 3.00 & 5.00 & 4.5228 & .58497 \\
\hline
\end{tabular}


Arab World English Journal (AWEJ) 2nd Special Issue on Covid 19 Challenges January 2022

Al-Bargi

\begin{tabular}{|l|c|c|c|c|c|}
\hline $\begin{array}{l}18 \text { The two skills I'd prefer to assess } \\
\text { in person are speaking and writing. }\end{array}$ & 241 & 1.00 & 3.00 & 1.7552 & .49395 \\
\hline $\begin{array}{l}19 \text { Remote online writing assessment } \\
\text { is more convenient to conduct than } \\
\text { onsite assessment. }\end{array}$ & 241 & 1.00 & 4.00 & 2.0747 & .58685 \\
\hline $\begin{array}{l}20 \text { Remote online writing assessment } \\
\text { is less stressful for students than } \\
\text { writing assessment conducted on } \\
\text { campus. }\end{array}$ & 241 & 1.00 & 3.00 & 2.0207 & .50372 \\
\hline $\begin{array}{l}21 \text { A blended style (onsite-online) } \\
\text { writing assessment is a good } \\
\text { approach to measure writing ability. }\end{array}$ & 241 & 1.00 & 3.00 & 2.0290 & .66707 \\
\hline $\begin{array}{l}22 \text { Online writing assessment has } \\
\text { increased students' digital literacy. }\end{array}$ & 241 & 1.00 & 4.00 & 1.9585 & .59716 \\
\hline Valid N (listwise) & 241 & & & & \\
\hline
\end{tabular}

Like the above opinions, there were some comments echoed by teacher participant $\mathrm{C}$ (female) who mentioned:

"The remote online writing assessment has its pros and cons in my opinion. I like conducting remote online assessment because it's a bit more convenient for me. I can control the number of scripts I grade at my own pace. However, there is this element of authenticity which hinders the guarantee that the student hasn't received any support, whether approved or unapproved, from anyone".

Participant D (male teacher) expressed his perception of how to ensure academic integrity of remote online learning by saying:

"It is a tough question. I think there are always compromises in dire situations. We were confronted with the Covid-19 pandemic, and we went into lockdown with full mode online education and as such, we benefited from this experience and at the same time faced some issues. However, it is what was available for us at the time. If I was to suggest ensuring academic integrity, I could ask the students to switch on their webcams, if that's possible. We could also ask the student to sit the exams at our centres, like we have at our institute, with certain measures such as social distancing".

Questions 23-25 of the survey probes whether the teachers found any positive aspects of online writing assessments and the online teaching of writing. Item 23 showed that a strong majority of the teachers believed that online teaching had expanded their skills in teaching writing and assessing it online. A strong majority also agreed that it is easier to grade typed student assessments than handwritten assessments (Item 24). A slight majority agreed that students can finish more writing exercises online than on a piece of paper in the same amount of time (Item 25). Table 12 below highlights these findings.

Table 12. Descriptive Statistics (Items 23-25).

\begin{tabular}{|l|c|c|c|c|c|}
\hline & $\mathrm{N}$ & Minimum & Maximum & Mean & Std. Deviation \\
\hline $\begin{array}{l}\text { 23 Online teaching has expanded } \\
\text { my skills in teaching writing and } \\
\text { assessing it online. }\end{array}$ & 241 & 1.00 & 3.00 & 1.6639 & .50735 \\
& & & & & \\
\hline
\end{tabular}


Arab World English Journal (AWEJ) 2nd Special Issue on Covid 19 Challenges January 2022

Exploring Online Writing Assessment Amid Covid-19

Al-Bargi

\begin{tabular}{|l|c|c|c|c|c|}
\hline $\begin{array}{l}\text { 24 It is easier to grade typed student } \\
\text { assessments than handwritten } \\
\text { assessments. }\end{array}$ & 241 & 1.00 & 4.00 & 1.8299 & .74729 \\
\hline $\begin{array}{l}\text { 25 Students can finish more writing } \\
\text { exercises online than on a piece of } \\
\text { paper in the same amount of time. }\end{array}$ & 241 & 1.00 & 4.00 & 2.5560 & .71733 \\
\hline
\end{tabular}

The interviews also showed that the teachers found some positive aspects regarding the migration from onsite to online teaching. Participant E (male) expressed his opinion by saying:

"If we take a holistic view of the migration from on site to online and the benefits that we have certainly received, we can see that some teachers were either inexperienced in digital teaching and online teaching or they had a little bit of experience and this change made them much more confident in their teaching online and possibly generating a strong foundation for various courses. Also, we did manage to address some of the issues of time management, quizzes and assessments. Perhaps we can assume that we came up with new ideas of learning and also some sort of road maps that the students can follow in their online learning."

Participant F (female teacher) said:

"It was just a matter of time before this migration occurred. Covid-19 speeded things up and has generated the momentum for the migration from onsite to online and as such, the manifestation of a new education reality. The students became more aware of digital education. They learned about plagiarism and policies of submission using different platforms. We saw many benefits to the online environment, and we became more aware of solutions to various issues that occurred in online teaching and learning".

\section{Part III: Perceptions on cheating in Online Writing Assessment:}

As noted previously, teachers were doubtful whether the submitted online written work reflected their students' true proficiency (Item 10); they were doubtful that a remote unproctored writing assessment could be as authentic as onsite assessment (Item 11); and they strongly agreed that it was difficult to verify the authenticity of online writing tasks if they were done remotely (Item 13). They also thought that a good number of their students had received unauthorized help (Item 14). At the same time, however, the vast majority reported an inability to provide definitive evidence of cheating in remote unproctored writing assignments (Item 15).

Items 26-30 (see the table below) focused on institutional plagiarism policies and to what extent students were familiar with them. Item 26 shows that the majority of the teachers believe that students were aware of what constitutes plagiarism. The majority of the teachers also said that their institutes provide students with plagiarism reports on their submitted work (Item 27) and they strongly agreed that their institutes encourage teachers to report cheating (Item 28). Many teachers said that their institutes have strict and zero tolerance policies towards cheating on online writing assessments (Item 29). However, teachers were not convinced that their institutes have developed effective ways to mitigate cheating in online assessment (Item 30). 
Arab World English Journal (AWEJ) 2nd Special Issue on Covid 19 Challenges January 2022

Considering the responses to Items 10-15 and Items 26-30, it appears that teachers are highly suspicious that cheating is occurring in unproctored online written assessments even though students understand what plagiarism is and their institutes have strict policies. The problem seems to be the difficulty of providing definitive evidence of cheating in these types of assessments as was strongly reflected in the responses to Item 15. These findings are illustrated in Table 13.

Table 13. Descriptive Statistics (Items 26-30).

\begin{tabular}{|c|c|c|c|c|c|}
\hline & $\mathrm{N}$ & Min & Max & Mean & Std. Deviation \\
\hline $\begin{array}{l}26 \text { Students are aware of what constitutes } \\
\text { plagiarism and cheating. }\end{array}$ & 241 & 1.00 & 5.00 & 2.5519 & 1.33167 \\
\hline $\begin{array}{l}27 \text { Our institute provides students with plagiarism } \\
\text { and similarity reports on their submitted work. }\end{array}$ & 241 & 1.00 & 5.00 & 2.2199 & 1.16788 \\
\hline $\begin{array}{l}28 \mathrm{I} \text { am ready to report and encouraged to report } \\
\text { cheating cases in online assessment when } \\
\text { detected. }\end{array}$ & 241 & 1.00 & 3.00 & 1.7469 & .68787 \\
\hline $\begin{array}{l}29 \text { Our institute has a strict zero-tolerance policy } \\
\text { towards cheating on online writing assessments. }\end{array}$ & 241 & 1.00 & 4.00 & 1.9378 & .91302 \\
\hline $\begin{array}{l}30 \text { Our institute has now developed effective } \\
\text { ways to mitigate cheating in online assessment. }\end{array}$ & 241 & 1.00 & 5.00 & 2.6349 & 1.08756 \\
\hline Valid N (listwise) & 241 & & & & \\
\hline
\end{tabular}

The findings were further corroborated by statements from the participating teachers during the semi-structured interviews. Participant $\mathrm{H}$ (female) stated:

"The migration to online teaching remotely brought with it various issues as well as opportunities for us teachers to adjust and tweak our teaching in such a unique environment. However, one issue that was a concern of mine is authenticity of the online written assessment which our department deliberated extensively to ameliorate".

Participant A (male) injected a note of stark reality into the issue of authenticity and cheating in remote online writing assessment by stating:

"Our institute tried various approaches to combat any cheating on the online writing assessment; however, the most effective way was to ask the students to conduct their assessment at the university premises with preventive health measures such as social distancing and wearing face masks at all times".

\section{Discussion}

This research attempted to answer three main questions regarding the migration from fully onsite teaching and learning to fully online teaching and learning. These questions are: (1) What impact has the migration from onsite to online writing assessment had on the assessment of 
writing as perceived by EFL teachers? (2) What are the challenges that EFL teachers have experienced with regards to writing assessment as a result of fully online teaching and learning? (3) What are the advantages and positive outcomes that EFL teachers have gained during the fully online L2 writing teaching and assessment which resulted from the Covid-19 lockdown?

In particular, the research aimed at exploring teachers' perceptions of the impact that the transformation has had on the assessment of writing, the challenges teachers have faced in online writing assessment, and the advantages or positive outcomes which have come from the sudden shift to the online teaching and assessment of writing as a result of Covid-19.

\section{Impact and Challenges on the Assessment of Writing}

Teachers also voiced their concerns that remote online writing assessment can be a challenge because it is difficult to assure academic integrity and whether the students may have received unauthorised help and assistance. This is also in agreement with various research studies by Alghamdi et al. (2016), Olt (2002) and (Sileo \& Sileo, 2008). As such, teachers were suspicious of the authenticity of the work submitted in online unproctored writing exams, and they strongly prefer in person assessment of speaking and writing. Although plagiarism policies exist and students are aware of what plagiarism is, the enforcement of such policies was very difficult due to the lack of definitive evidence of cheating.

\section{Positive Outcomes from the Shift to Online Teaching and Assessment of Writing}

From what was reported and analysed earlier, the following are the main positive outcomes:

- Remote online writing assessment is easier to conduct (Item 19)

- It is less stressful for students (Item 20)

- It has increased students' digital literacy (Item 22)

- Typed assignments are easier to grade (Item 24)

- Online writing exercises are faster (Item 25)

- It has expanded teachers' skills (Item 23)

We can see from the results of the data analysis that the teachers have gained an enormous amount of information and practical experience from online teaching and learning. We can see that the teachers appreciated and welcomed the new experience of full time remote online learning. It has provided them with new professional experiences, and they have managed to learn a great deal about the new environment. This is in agreement with Kidd and Murray (2020) as well as Md Yunus et al. (2021), who elaborated on the need to accommodate the new environment with the proper pedagogical methods.

Several teachers have expressed gratitude for the new experience with fully online learning since they have learned a great deal about teaching in a purely online environment. The students also benefited from the shift, becoming more aware of education within the digital environment, and more savvy about the various platforms available for online teaching and learning. This is in agreement with Md Yunus et al. (2021) and König et al. (2020) who stressed the need to adapt to a fully online teaching and learning environment for both teachers and students. 


\section{Conclusion}

We live in a constantly changing world and the dynamics of education change with changing parameters to meet the needs of the learners. This convergent parallel mixed-methods research attempted to explore how EFL teachers view the changes from onsite to online writing assessment. Shifting education paradigms always require preparation and adoption of effective pedagogies to meet the needs of the students and assess them fairly and efficiently. Several teachers saw the migration from onsite to online as an opportunity for professional development and a chance to acquire teaching expertise in both settings. As such, leaders, decision-makers and policymakers as well as stakeholders in education, must ask themselves whether they are prepared for various changes and transformations that may occur over a long or short period of time. Taking into consideration various elements of remote writing assessment is but one challenge demanding various approaches, including monitored online assessments. Similar requirements for other EFL online teaching and learning need to be examined and discussed with the teachers in order to make the migration smooth and efficient.

With the Covid-19 pandemic and the mandatory lockdown protocols that followed immediately, led to the interruption of the onsite education process and the commencing of the full mode remote online teaching and learning. The process, according to the views expressed by a majority of teachers, was not a mere negative experience, but rather, an opportunity for many positive outcomes and newly acquired professional experience in the ELT realm. The EFL teachers who participated in the study openly expressed their views regarding how the sudden migration from onsite to online teaching and learning affected their pedagogical approach and the challenges they faced, especially in terms of online writing assessment. It is quite predictable that teachers voiced their concerns about the sudden changes. Additionally, teachers perceive cheating to be a huge and relatively unenforceable issue in remote online writing assessment. They did not object to the online remote writing assessment per se; they only voiced their concerns regarding such an assessment when it is unproctored.

\section{Recommendations}

Several outcomes of this research study have led to the affirmation of the need for drafting various contingency plans in education as well as the formation of certain committees that encompass members who have expertise in the various realms of the education processes. Perhaps, the establishment of a designated unit that drafts certain plans and future policies in order to allow for the smooth transformation of education processes as per meeting the needs of the learners in different educational scenarios.

\footnotetext{
About the author

Abdullah Al-Bargi is Associate Professor of Applied Linguistics and currently serves as the President of Saudi TESOL and Dean of the English Language Institute (ELI), King Abdulaziz University (KAU), Jeddah, Saudi Arabia. Dr. Al-Bargi had previously served as the ELI ViceDean for Development for seven years. Dr. Al-Bargi obtained his MA and $\mathrm{PhD}$ from Arizona State University, Tempe, AZ, USA. ORCiD: https://orcid.org/0000-0001-9002-3860
} 
Arab World English Journal (AWEJ) 2nd Special Issue on Covid 19 Challenges January 2022

\section{References}

Alghamdi, E. A., Rajab, H., \& Rashid, S. (2016). Unmonitored students self-created WhatsApp groups in distance learning environments: A collaborative learning tool or cheating technique. International Journal of Research Studies in Educational Technology, 5(2), 71-82.

Almossa, S. Y. (2021). University students' perspectives toward learning and assessment during COVID-19. Education and Information Technologies, 1-19.

AlTameemy, F. A., Alrefaee, Y., \& Alalwi, F. S. (2020). Using Blackboard as a Tool of EAssessment in Testing Writing Skill in Saudi Arabia. Asian ESP, 16(6.2).

Althaqafi, A. S. (2018). THE CHANGING PURPOSES AND PRINCIPLES OF ASSESSMENT IN SAUDI ARABIA: IMPLICATIONS FOR TEACHERS. European Journal of Education Studies.

Atmojo, A. E. P., \& Nugroho, A. (2020). EFL classes must go online! Teaching activities and challenges during COVID-19 pandemic in Indonesia. Register Journal, 13(1), 49-76.

Austin, J., Burke, A., Foley, E., \& Rumohr, G. (2021). Building and Maintaining Sanctuary Spaces through Face to Face Writing Assessment. Teaching/Writing: The Journal of Writing Teacher Education, 10(1), 4.

Balouchi, S., \& Samad, A. A. (2021). No more excuses, learn English for free: Factors affecting L2 learners intention to use online technology for informal English learning. Education and Information Technologies, 26(1), 1111-1132. https://doi.org/10.1007/s10639-020$10307-\mathrm{Z}$

Bitchener, J. (2008). Evidence in support of written corrective feedback. Journal of second language writing, 17(2), 102-118.

Brown, D. (2012). The written corrective feedback debate: Next steps for classroom teachers and practitioners. Tesol Quarterly, 46(4), 861-867.

Creswell, J. W. (2014). A Concise Introduction to Mixed Methods Research. SAGE Publications. https://books.google.com.sa/books?id=XQPbwAEACAAJ

Godwin-Jones, R. (2018). Second language writing online: An update. Language Learning \& Technology, 22(1), 1-15.

Grami, G. M. A. (2010). The effects of integrating peer feedback into university-level ESL writing curriculum: A comparative study in a Saudi context Newcastle University].

Griffith, P. (2014). Impacts of online technology use in second language writing: A review of the literature. Reading Improvement, 51(3), 303-312.

Guo, Q., \& Xu, Y. (2021). Formative assessment use in university EFL writing instruction: a survey report from China. Asia Pacific Journal of Education, 41(2), 221-237.

Han, S., \& Shin, J.-A. (2017). Teaching Google search techniques in an L2 academic writing context. Language Learning \& Technology, 21(3), 172-194.

Jiang, Z., Wu, H., Cheng, H., Wang, W., Xie, A. N., \& Fitzgerald, S. R. (2021). Twelve tips for teaching medical students online under COVID-19. Medical education online, 26(1), 1854066.

Jianling, L. (2018). The impact of face-to-face oral discussion and online text-chat on L2 Chinese writing. Journal of second language writing, 41, 27-40.

Kidd, W., \& Murray, J. (2020). The Covid-19 pandemic and its effects on teacher education in England: How teacher educators moved practicum learning online. European Journal of Teacher Education, 43(4), 542-558. 
Arab World English Journal (AWEJ) 2nd Special Issue on Covid 19 Challenges January 2022

Klenke, K., Martin, S. S., \& Wallace, J. R. (2016). Qualitative Research in the Study of Leadership. Emerald Group Publishing Limited. https://books.google.com.sa/books?id=N19oCwAAQBAJ

König, J., Jäger-Biela, D. J., \& Glutsch, N. (2020). Adapting to online teaching during COVID19 school closure: teacher education and teacher competence effects among early career teachers in Germany. European Journal of Teacher Education, 43(4), 608-622.

Md Yunus, M., Ang, W. S., \& Hashim, H. (2021). Factors Affecting Teaching English as a Second Language (TESL) Postgraduate Students' Behavioural Intention for Online Learning during the COVID-19 Pandemic. Sustainability, 13(6), 3524. https://www.mdpi.com/2071-1050/13/6/3524

Mihai, F. (2010). Assessing English language learners in the content areas: A research-intopractice guide for educators. University of Michigan Press.

Mondol, M. S., \& Mohiuddin, M. G. (2020). Confronting Covid-19 with a paradigm shift in teaching and learning: A study on online classes. International Journal of Social, Political and Economic Research, 7(2), 231-247.

Nardi, P. M. (2018). Doing Survey Research: A Guide to Quantitative Methods. Taylor \& Francis. https://books.google.com.sa/books?id=lFgPEAAAQBAJ

Obeid, R. (2017). Second Language Writing and Assessment: Voices from within the Saudi EFL Context. English language teaching, 10(6), 174-181.

Olt, M. R. (2002). Ethics and distance education: Strategies for minimizing academic dishonesty in online assessment. Online journal of distance learning administration, 5(3), 1-7.

Penrod, D. (2005). Composition in Convergence: The Impact of New Media on Writing Assessment. Taylor \& Francis. https://books.google.co.uk/books?id=hnSRAgAAQBAJ

Rajab, H. (2018). EFL Teachers and Learners' Perceptions, Beliefs and Practices on Written Corrective Feedback in the Saudi Higher Education Context.

Sahidu, H., Gunawan, G., Herayanti, L., Indriaturrahmi, I., Astutik, F., \& Bon, A. T. (2019). The Development of E-Assessment with Learning Management System. Proceedings of the International Conference on Industrial Engineering and Operations Management Pilsen, Czech Republic,

Saldana, J. (2021). The Coding Manual for Qualitative Researchers. SAGE Publications. https://books.google.com.sa/books?id=X7T5DwAAQBAJ

Shin, D., Kwon, S. K., \& Lee, Y. (2021). The effect of using online language-support resources on L2 writing performance. Language Testing in Asia, 11(1), 4. https://doi.org/10.1186/s40468-021-00119-4

Sileo, J. M., \& Sileo, T. W. (2008). Academic dishonesty and online classes: A rural education perspective. Rural Special Education Quarterly, 27(1-2), 55-60.

Subekti, A. S. (2021). Covid-19-triggered online learning implementation: Pre-service English teachers' beliefs. Metathesis: Journal of English Language, Literature, and Teaching, 4(3), 232-248.

Tavakol, M., \& Dennick, R. (2011). Making sense of Cronbach's alpha. International journal of medical education, 2, 53.

Waer, H. W. (2020). BELIEVE now I'm good enough to write an essay": Using a process-genre approach to enhance L2 writing self-efficacy and writing performance. مجلة كلية التربية في العلوم التثربوية, 44(4), 298-253. 
Arab World English Journal (AWEJ) 2nd Special Issue on Covid 19 Challenges January 2022

Yang, B., \& Huang, C. (2021). Turn crisis into opportunity in response to COVID-19: experience from a Chinese University and future prospects. Studies in Higher Education, 46(1), 121-132. https://doi.org/10.1080/03075079.2020.1859687

Yi, Y., \& Jang, J. (2020). Envisioning possibilities amid the COVID-19 pandemic: Implications from English language teaching in South Korea. TESOL Journal, 11(3), e00543. https://doi.org/10.1002/tesj.543

Yudkowsky, R., Park, Y. S., \& Downing, S. M. (2019). Assessment in Health Professions Education. Taylor \& Francis. https://books.google.com.sa/books?id=0a-1DwAAQBAJ

Zou, M., Kong, D., \& Lee, I. (2021). Teacher Engagement with Online Formative Assessment in EFL Writing During COVID-19 Pandemic: The Case of China. The Asia-Pacific Education Researcher, 1-12.

Zyad, H. (2016). L2 writing development: The case of two high-achieving and two struggling college-level students. International Journal for 21 st Century Education, 3(1), 25-36.

\section{Appendices}

Table 3. Area of Employment in Saudi Arabia

\begin{tabular}{|l|l|c|c|c|c|}
\hline \multicolumn{2}{|l|}{ 2. Where do you work in Saudi Arabia? } & & & $\begin{array}{c}\text { Cumulative } \\
\text { Percent }\end{array}$ \\
\hline \multirow{3}{*}{ Valid } & Frequency & Percent & Valid Percent & 12.0 \\
\cline { 2 - 6 } & Eastern Region & 29 & 12.0 & 12.0 & 70.1 \\
\cline { 2 - 6 } & Western Region & 140 & 58.1 & 58.1 & 84.6 \\
\cline { 2 - 6 } & Central Region & 35 & 14.5 & 14.5 & 96.7 \\
\cline { 2 - 6 } & Southern Region & 29 & 12.0 & 12.0 & 100.0 \\
\cline { 2 - 6 } & Northern Region & 8 & 3.3 & 3.3 & \\
\cline { 2 - 6 } & Total & 241 & 100.0 & 100.0 & \\
\hline
\end{tabular}

Table 4. Highest Qualifications

\section{Appendix B}

\begin{tabular}{|c|c|c|c|c|c|}
\hline \multicolumn{6}{|c|}{ 3. What is your highest qualification in English Language Teaching (ELT)? } \\
\hline & & Frequency & Percent & Valid Percent & $\begin{array}{c}\text { Cumulative } \\
\text { Percent }\end{array}$ \\
\hline \multirow[t]{6}{*}{ Valid } & CELTA & 14 & 5.8 & 5.8 & 5.8 \\
\hline & DELTA & 13 & 5.4 & 5.4 & 11.2 \\
\hline & TEFL Diploma & 14 & 5.8 & 5.8 & 17.0 \\
\hline & MA TEFL/TESOL & 141 & 58.5 & 58.5 & 75.5 \\
\hline & $\begin{array}{l}\text { Ph.D/Ed.D Applied } \\
\text { Ling./TEFL/TESOL }\end{array}$ & 59 & 24.5 & 24.5 & 100.0 \\
\hline & Total & 241 & 100.0 & 100.0 & \\
\hline
\end{tabular}

Table 5. Years of Experience in the ELT field 4. How many years of experience do you have in the ELT field?

\begin{tabular}{|l|l|l|c|} 
Frequency & Percent & Valid Percent & $\begin{array}{c}\text { Cumulative } \\
\text { Percent }\end{array}$ \\
\hline
\end{tabular}


Arab World English Journal (AWEJ) 2nd Special Issue on Covid 19 Challenges January 2022 Exploring Online Writing Assessment Amid Covid-19

Al-Bargi

\begin{tabular}{|l|l|c|c|c|c|}
\hline \multirow{5}{*}{ Valid } & $0-5$ years & 44 & 18.3 & 18.3 & 18.3 \\
\cline { 2 - 5 } & $6-10$ years & 36 & 14.9 & 14.9 & 33.2 \\
\cline { 2 - 5 } & $11-15$ years & 61 & 25.3 & 25.3 & 58.5 \\
\cline { 2 - 5 } & $16-20$ years & 63 & 26.1 & 26.1 & 84.6 \\
\cline { 2 - 5 } & $21-25$ years & 8 & 3.3 & 3.3 & 88.0 \\
\cline { 2 - 5 } & $26-30$ years & 13 & 5.4 & 5.4 & 93.4 \\
\cline { 2 - 5 } & $>30$ years & 16 & 6.6 & 6.6 & 100.0 \\
\cline { 2 - 5 } & Total & 241 & 100.0 & 100.0 & \\
\hline
\end{tabular}

\section{Appendix D}

Table 6. Years of Experience in online teaching

\begin{tabular}{|l|l|c|c|c|c|}
\hline \multicolumn{2}{|l|}{ 5. How many years of experience do you have in online teaching? } \\
\hline \multirow{4}{*}{ Valid } & Frequency & Percent & Valid Percent & $\begin{array}{c}\text { Cumulative } \\
\text { Percent }\end{array}$ \\
\cline { 2 - 6 } & $0-3$ years & 202 & 83.8 & 83.8 & 83.8 \\
\cline { 2 - 6 } & $4-6$ years & 21 & 8.7 & 8.7 & 92.5 \\
\cline { 2 - 6 } & $7-10$ years & 7 & 2.9 & 2.9 & 95.4 \\
\cline { 2 - 6 } & $11-13$ years & 7 & 2.9 & 2.9 & 98.3 \\
\cline { 2 - 6 } & $>13$ years & 4 & 1.7 & 1.7 & 100.0 \\
\cline { 2 - 6 } & Total & 241 & 100.0 & 100.0 & \\
\hline
\end{tabular}

\section{Appendix E}

Table 7. Type of academic semester

\begin{tabular}{|c|c|c|c|c|c|}
\hline \multicolumn{6}{|c|}{$\begin{array}{l}\text { 6. What types of academic semesters do you have in the English language program at your } \\
\text { institution? }\end{array}$} \\
\hline & & Frequency & Percent & Valid Percent & $\begin{array}{l}\text { Cumulative } \\
\text { Percent }\end{array}$ \\
\hline \multirow[t]{3}{*}{ Valid } & Full Semester (15 weeks) & 134 & 55.6 & 55.6 & 55.6 \\
\hline & Modular (7 weeks) & 107 & 44.4 & 44.4 & 100.0 \\
\hline & Total & 241 & 100.0 & 100.0 & \\
\hline
\end{tabular}

\section{Appendix F}

Table 8. Type of courses taught

\begin{tabular}{|l|c|c|}
\hline Type of Course & Number participants & $\%$ \\
\hline Academic English & 40 & $17 \%$ \\
\hline PYP English & 31 & $13 \%$ \\
\hline General English & 48 & $20 \%$ \\
\hline Mixture of courses & 122 & $51 \%$ \\
\hline
\end{tabular}

\section{Appendix G}

Table 9. Nature of remote online writing assessments

\begin{tabular}{|c|c|c|c|c|c|}
\hline \multicolumn{6}{|c|}{$\begin{array}{l}\text { 8. When you were involved in grading remote online writing assessments, were these } \\
\text { assessments: }\end{array}$} \\
\hline & & Frequency & Percent & Valid Percent & $\begin{array}{l}\text { Cumulative } \\
\text { Percent }\end{array}$ \\
\hline \multirow[t]{5}{*}{ Valid } & Proctored & 52 & 21.6 & 21.6 & 21.6 \\
\hline & unproctored & 120 & 49.8 & 49.8 & 71.4 \\
\hline & sometimes proctored & 42 & 17.4 & 17.4 & 88.8 \\
\hline & sometimes unproctored & 27 & 11.2 & 11.2 & 100.0 \\
\hline & Total & 241 & 100.0 & 100.0 & \\
\hline
\end{tabular}

